\title{
Milyen kapcsolatban állnak a közszféra reformjai a gazdaságpolitikai paradigmákkal?
}

\begin{abstract}
$\mathrm{Az}$ állam szerepének kérdése mindig is foglalkoztatta a közgazdász-társadalmat. Az egyes gazdaságpolitikai paradigmák kiemelt szerepet szántak az állami beavatkozáshoz füződő kérdések megvitatásának. Arra azonban, hogy az állam miként is oldja meg feladatait, már kisebb figyelem irányul. A 20. évszázad utolsó harmadában - párhuzamosan a keynesi gazdaságpolitikával - megingott a weberi bürokráciába vetett hit, új, az államháztartás müködésének megreformálását célzó irányzatok kerültek előtérbe. Ilyennek tekinthetjük az új közszolgálati menedzsment, a jó kormányzás irányzatát és az új weberiánus megközelítést. Bár ezek a fogalmak különböző elméleti alapokon nyugszanak, sok esetben vezettek hasonló szervezeti változásokhoz. A tanulmány célja megvizsgálni azt, hogy a különböző időszakokban megjelenő államszervezési elméletek milyen kapcsolatban állnak a gazdaságpolitikai paradigmákkal. A feldolgozott irodalmak arra utalnak, hogy az államtól várt szabályozás mértéke (a reguláció vagy a dereguláció irányába történő elmozdulások), valamint az állam és a társadalom viszonya meghatározza az államszervezet formáját, jellemzőit. ${ }^{*}$ Journal of Economic Literature (JEL) kód: H83.
\end{abstract}

Az állam szerepével kapcsolatos kérdéseket a közgazdasági gondolkodás egyik központi témájának tekinthetjük. Az átfogó paradigmák foglalkoznak az állam szerepét, méretét, aktivitásának szükségességét feszegető kérdésekkel. Azzal kapcsolatban azonban, hogy az állam a paradigmák alapján miként oldja meg feladatait,

* A kutatást az EFOP-3.6.2-16-2017-00007 azonosítószámú, Az intelligens, fenntartható és inkluzív társadalom fejlesztésének aspektusai: társadalmi, technológiai, innovációs hálózatok a foglalkoztatásban és a digitális gazdaságban című projekt támogatta. A projekt az Európai Unió támogatásával, az Európai Szociális Alap és Magyarország költségvetése társfinanszírozásában valósul meg.

A szerző köszönetét fejezi ki Voszka Évának, Kovács Árpádnak, valamint az anonim lektornak a kézirat korábbi változatához füzött konstruktív észrevételeikért.

A „fejlesztő állam” koncepcióját illetően korántsem alakult ki egyetértés sem a közgazdaságtanban, sem a gazdaságpolitikában. A téma iránt érdeklődő olvasóink figyelmét felhívjuk az ugyane lapszámunkban megjelent könyvrecenzióra. - A szerk.

Tóth Balázs tanársegéd, Szegedi Tudományegyetem Gazdaságtudományi Kar (e-mail: tothbalazs@ eco.u-szeged.hu).

A kézirat első változata 2020. július 22-én érkezett szerkesztőségünkbe.

DOI: http://dx.doi.org/10.18414/KSZ.2021.2.205 
már sokszor nem kapunk választ. Az állam által alkalmazott módszerek átvételéhez különböző elméletek kapcsolódnak, amelyeknek azonban közel sem egyértelmü a viszonya a tágabb összefüggésekben értelmezett paradigmákhoz.

Tanulmányunkban először arra a kérdésre keressük a választ, hogy mi az oka az államháztartási reformoknak. Hartley [2005] szerint a közszférában az innovációk nem termékekre vagy szolgáltatásokra vonatkoznak, hanem inkább a szolgáltató és a szolgáltatás igénybevevői közötti viszony megváltoztatására. Torma [2010] megállapítja, hogy az államszervezetek változásai a köz- és a magánszféra kapcsolatának módosulásaihoz is köthetők. Peters-Pierre [1998] kiemeli, hogy az állam felépítésében, eljárásaiban a magánszférához füződő viszonya is tükrözödik, a közszféra feladatszervezése a magánszférához füződő kapcsolatának megváltozásából fakadt. Tehát a közszféra módszertani újításait nem tudjuk a társadalom más eseményeitől teljesen izolálni. Ezt megerősíti Meyer-Sahling-Yesilkagit [2011] azon megállapítása is, amely szerint az államháztartások müködése útfüggö, az alkalmazott módszerek körét befolyásolják kulturális tényezők, hagyományok és egyéb körülmények is. Például a posztszocialista országok körében is megfigyelhetők az előző rendszer lenyomatai: a szervezeti instabilitás és a ragaszkodás a diszkrecionális személyi vezetéshez (Meyer-Sahling [2009]).

Az elmúlt évtizedekben azonban számos országban a közszféra jó néhány területén jelentek meg új megoldások. Az angolszász országokban az új közszolgálati menedzsment (new public management) irányzata került elötérbe, amely szerint az elszámoltathatóság fokozható, ha átültetik a magánszféra müködési és vezetési elveit, s mérséklik a köz- és a magánszféra közötti különbségeket (Hood [1995]). A közszféra reformjai esetében azonban az újításhoz vezető okok jellemzően mások, mint a magánszférában. Az állam müködésének megújításában nemcsak az elérhető elönyök realizálása iránti igény felerősödése figyelhető meg, hanem más külső tényezők is befolyással lehetnek. $\mathrm{Az}$ egyes reformok tartalmára és időzítésére országspecifikus belső és külső tényezők gyakorolnak hatást. Nyugat-Európában a közbizalom megerösítése, a makrogazdasági problémák (nagy államháztartás, költségvetési hiány, gyenge államháztartási teljesítmény) tekinthetők a változásokat előidéző okoknak (Bouckaert és szerzőtársai [2011]). Wright [1994] a nemzetközi kapcsolatok erősödését és az európia integrációt is olyan oknak tekintette, amelyek konvergáló államháztartási reformokhoz vezettek, de a politikai és technológiai környezet változásait is ilyen tényezőknek vélte. További okként pedig a gazdasági paradigmaváltást is említette.

A közép-európai országokban az államháztartások megújítása az 1990-es években indult meg. Ennek egyik fö oka természetesen a posztszocialista országok demokratizálódása volt, amely az állami adminisztrációban is megmutatkozott. A fejlettebb államokat jellemző megoldások megvalósításához változásokra volt szükség. Ezeket a törekvéseket a Gazdasági Együttmüködési és Fejlesztési Szervezet (OECD) SIGMA (Support for Improvement in Governance and Management) programja is szorgalmazta, valamint az Európai Unió PHARE (Poland and Hungary: Assistance for Restructuring their Economies) elnevezésü programja pénzügyi támogatást is nyújtott az intézményrendszer és az adminisztráció megújitásához (Bouckaert és szerzötársai [2011]), a Nemzetközi Valutaalap és a Világbank szerepét is ki lehet emelni (Pongrácz [2016]). Ezeket a DiMaggio-Powell [1983] által említett izomorfizmusok (kényszerítö, 
utánzó és normatív) megnyilvánulásának tekinthetjük. Kelet-Európa országai esetében tehát a politikai és társadalmi átrendeződés maga után vonta az államháztartási folyamatok megújítását is. A kelet-közép-európai országok reformjaival kapcsolatban több problémát lehet kiemelni. A kilencvenes években jellemzően nem történtek érdemi reformok, a változások tervek, stratégiák nélkül valósultak meg. Az átalakulások sürgőssége és a döntéshozók tapasztalatlansága miatt az egyes megoldások kockázatait nem mérték fel megfelelően, inkább egy erős utánzó mechanizmusként lehet leírni az állam szervezésével kapcsolatos döntéseket (Randma-Liiv [2008]). Wise [2002] a politikai indíttatás mellett még két normatív mechanizmust nevezett meg a közigazgatás reformjai kapcsán, mégpedig a gazdaságossági és költségvetési okokat, valamint a társadalom értékpreferenciáinak a változását.

Ebben a tanulmányban az állam szerepének és a közszféra szervezeti változásainak párhuzamba állításával kívánjuk feltárni a közöttük lévő kapcsolatot. Elöször röviden áttekintjük, hogy az egyes időszakokban uralkodó paradigmák milyen szerepet szántak az államnak, illetve hogyan vélekedtek az állam gazdaságban való részvételéről. Ezt követően kitérünk a weberiánus (gyakran hagyományosként említett) államszervezeti forma jellegzetességeire, illetve háttérbe szorulásának okaira. Majd a weberi államszervezet megújítására irányuló megközelítések alapjait, illetve az ezekre épülő kormányzati irányzatokat mutatjuk be, és kitérünk a velük kapcsolatos tapasztalatokra is. Végül a tanulmány a következtetések összegzésével zárul.

\section{Az állam szerepének felfogása}

Az állam szerepe mindig is az egyes paradigmák központi kérdése volt, nem volt ez másképp a 18. században sem. A korszak liberális közgazdaságáról és Adam Smithről sokaknak a „láthatatlan kéz” és a „természetes szabadság” jut eszébe elsőként, valamint az, hogy az általuk vezérelt, spontán müködő piac lehet a gazdasági tevékenység és a gazdasági egyensúly alapja. Smith azonban nem tekintette marginálisnak az állam szerepét, és rámutatott a piaci müködés korlátaira is. A rend megőrzése („megvédje a társadalmat az erőszaktól és más független társadalmak inváziójától”), a társadalmi igazság biztosítása („,amennyire lehetséges, védje meg a társadalom minden tagját az igazságtalanságtól vagy annak minden más tagja által történő elnyomástól”) mellett bizonyos szolgáltatások létrehozáát is („létrehozzon bizonyos közműveket") állami feladatnak tekintette (Farkas [2017] 1. rész 48. o.). Indokolt körülmények között Ricardo is elfogadhatónak tartotta a kereskedelem állami korlátozását, illetve a protekcionista intézkedéseket Mill sem vetette el teljesen. A liberális és a neoklaszszikus közgazdászok is elismerték a piac tökéletlenségét, így a spontán piaci müködés kizárólagosságát sem tartották kívánatosnak (Szentes [2006]).

A következő évszázadot erősödő állami jelenlét jellemezte a fejlett régiókban. Európában az első világháború során különböző stratégiai ágazatok kerültek állami tulajdonba. Az állami tulajdon növekedése folytatódott a háború után is, a kedvező tapasztalatok, valamint a békekötés után kialakuló bizonytalan helyzet miatt (Voszka [2015]). A gazdasági világválság is az állami szerepvállalás növelésének irányába 
hatott. Az ekkor bekövetkező gazdaságpolitikai irányváltás elméleti alapjait Keynes fektette le, amivel az állam alapvető gazdasági szerepe évtizedekig megkérdőjelezhetetlenné vált (Farkas [2011]). A keynesi megközelítés alaptétele volt, hogy a költségvetési politika hatékonyabb, mint a monetáris politika, így az állami beavatkozást kívánatosnak tartotta, azonban a gazdaságpolitika nem a piac és a piaci mechanizmusok ellen jött létre (Szentes [2006]).

A második világháborút követő, viszonylag gyors fejlődésben fontos szerepe volt az államnak. Az állami aktivitás segített a konjunktúrahullámok kisimításában, valamint az exportképesség és a nemzetközi versenyképesség erösítésében (Farkas [2017] 1. rész). Fordulatot az olajválságok hoztak, ugyanis az állami szerepvállalás fokozásával nem lehetett megfelelően kezelni sem az 1973-as, sem az 1979-es olajválságot (Voszka [2015]), illetve a stagfláció jelenségére megfelelő választ nyújtani (Csaba [2010]). Az 1970-es években bekövetkezett stagnálást számos közgazdász az állam kudarcának tulajdonította, így annak szerepét minimalizáló, monetáris politikát elötérbe helyező törekvések vették kezdetüket. Lucas például ellenezte az állam gazdasági ciklusokat befolyásoló beavatkozásait, míg például Friedman szerint a monetáris politika elégséges a válságok megelözéséhez (Farkas [2017] 1. rész). Az 1980-as évek közgazdasági gondolkodásának alapját a neoliberalizmus jelentette. Uralkodó nézetté vált, hogy kemény pénzügypolitikai deregulációval és a kereskedelmi liberalizációval elérhető a gazdasági stabilitás és növekedés (Szentes [2006]). Ezeket az elveket fogalmazta meg a téma kapcsán sokszor emlegetett washingtoni konszenzus is. Az állam szerepének minimalizálását jelentős nemzetközi szervezetek is hangsúlyozták, mint például az IMF vagy az OECD. A periferikus vagy félperiferikus államok számára is erősen javallott volt a gazdaság liberalizációja és deregulációja (Farkas [2017] 1. rész). Igaz, ez a közvélekedés eleinte csak jól működő piacgazdaságokra vonatkozott (Kolodko [2000]). Ez magyarázza azt is, hogy a felzárkózó országok esetében miért más a tapasztalat. A délkelet-ázsiai országok figyelemre méltó felzárkózása a washingtoni konszenzussal részben ellentétes müködésnek volt köszönhetö (Stiglitz [1999]). A washingtoni konszenzus Kelet-Európában való alkalmazása sem váltotta be a hozzá füzött reményeket. A posztszocialista országokban nem léteztek azok az intézmények, amelyeket a fejlett országokban alapvetőnek tekinthetünk. Ezen országcsoport példája felhívta a figyelmet arra, hogy a privatizáció és a liberalizáció nem minden esetben hozza magával a gazdasági fejlődést. Mindez rávilágított az intézményi változások fontosságára (Kolodko [2000]).

A fóáramtól elszakadó délkelet-ázsiai országok gyors ütemű felzárkózásában jelentős szerepe volt a fejlesztő államnak (Wade [2010], [2014]), ám a 20. század utolsó évtizedében a délkelet-ázsiai országok, Oroszország és a latin-amerikai országok megingásait az állam túlzott gazdasági szerepének tulajdonították, s ezt a jelenséget a fejlesztö állam kudarcaként értékelték. Az idő előrehaladtával azonban egyre jobban kirajzolódott, hogy az említett válságok, illetve a 2001-2002-es világgazdasági kifulladás a neoliberális paradigma kudarcának tekinthető (Farkas [2017] 1. rész).

A 2007-2009-es válságot megelőző évtizedek tapasztalatai is cáfolták az állam túlzott visszaszorulását jósló nézeteket, ugyanis az államháztartás GDP-hez viszonyított aránya a fejlett országokban sem csökkent, igaz, a gazdasági szabadság növekedett 
(Muraközy [2009]). 2008 után Magyarországon még inkább felerősödtek az állami szerepvállalás fontosságát hangsúlyozó nézetek. Ezek nem egyértelmüen az állami beavatkozásoknak tulajdonították a válság kialakulását, hanem legalább részben a piac müködési elégtelenségét tekintették hatótényezőnek (Farkas [2017] 2. rész), a válság idején megerősödtek a kormányzati beavatkozást támogató hangok (Csaba [2010]). Mindezek ellenére valós paradigmaváltásról nem beszélhetünk, a válságot követően a közgazdasági gondolkodásban heterodoxia alakult ki (Csaba [2018]).

Ahogy a jelen fejezet rávilágított, a gazdaságpolitikai váltások miatt folyamatosan átértékelődött az állam szerepe. Ezzel párhuzamosan az államszervezetben is következtek be változások. Az innovatív megoldások közszférában való megjelenése, illetve „módszertani szempontból értelmezett” közeledése a magánszférához nagyjából azonos időszakra tehető a keynesiánus gazdaságpolitika háttérbe szorulásával. Vagyis a 20. században megfigyelhető a gazdaságpolitikai ciklusok és az államszervezeti reformok együtt mozgása, ami miatt érdemes megvizsgálni, hogy emögött állhat-e valamilyen közvetlen kapcsolat, vagy csak véletlen egybeesésről beszélhetünk.

\section{A modern államszervezés modelljei}

A következőkben áttekintjük a weberiánus állam alapvetö jellemzőit, valamint azokat az elméletek, amelyek megpróbálták más irányba terelni az állami feladatok szervezését. Az elméletek bemutatása mellett kitérünk a velük kapcsolatos tapasztalatokra is.

\section{A weberiánus állam}

Weber [1968] elméletében a bürokrácia alapját a racionális-legális legitimáció képezi, az autoritást maguk a személytelen utasítások jelentik. A weberi koncepció alapvető eleme a köz- és magánügyek szétválasztása, ezáltal a bürokraták magánügyeinek és hivatali tevékenységeiknek az elválasztása is. Szintén fontos szerepe van a hierarchiának és a hivatalos kapcsolatoknak. A modern államszervezetben a hivatalnokok nem tulajdonosai a feladatuk ellátásához biztosított eszközöknek. A politikailag független bürokraták alapos képzettséggel, speciális szaktudással rendelkeznek (Weber [1970] 383-385. o.). Jenei [2016] kiemelte, hogy a weberiánus államszervezetben élethivatásszerủen látják el a társadalom közügyeit a szakképzett hivatalnokok. A köztisztviselők jogszabályok által lefektetett kereteken belül, meghatározott hatáskörökben és feladatkörökben, hivatali szervezetekben, a hivatali út betartása mellett fejtik ki a tevékenységüket.

Mindezek következtében a közigazgatás kiszámíthatóan professzionálisan, nyitottan, valamint az ügyfél számára követhető módon müködik (1. ábra), ezáltal felülmúlva a korábbi korszakok közigazgatási modelljeit. A személyi állomány kinevezett (ennek alapját a képességeik jelentik), nem pedig választott, elömenetelüket a munkában tanúsított érdemeik határozzák meg (Jenei [2016]), meghatározott fizetésekkel rendelkezik, kinevezésük határozott idejü. A bürokrácia szervezetei jól meghatározott, elméletben indokolt célokkal rendelkeznek (Kaplan [1968]). 
1. ábra

A bürokratikus adminisztráció jellemzői

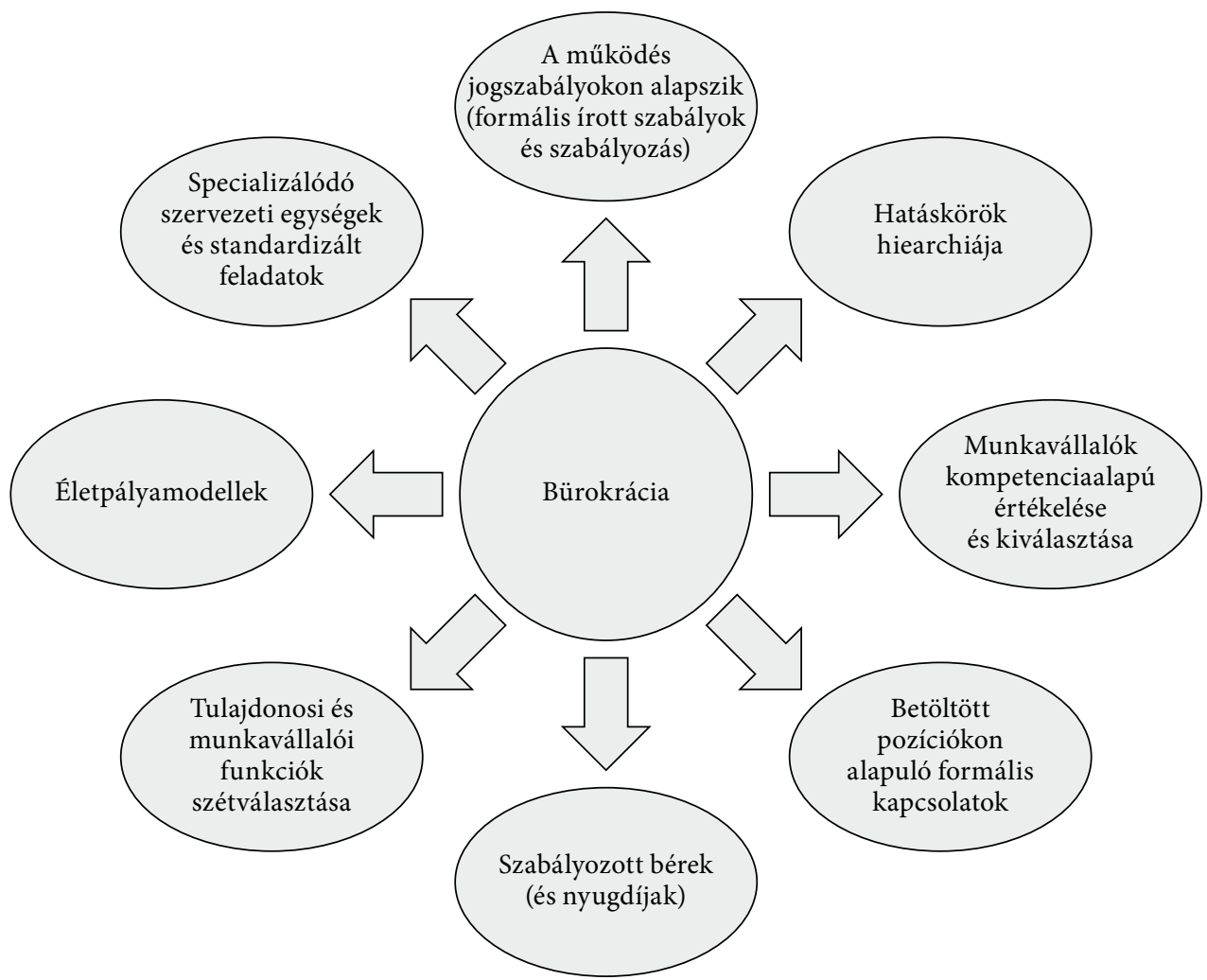

Forrás: saját szerkesztés Serpa-Ferreira [2019] alapján.

Weber bürokráciája úttörő volt a 20. század elején. A pozíciók és az azokat betöltő személyek elválasztása, a hierarchikus szervezetfelépítés, az írott dokumentumokra támaszkodás, illetve a szervezetek önzetlenségének szorgalmazása a közszféra alapjává vált. Néhány év alatt ezek az elvek az organizációk müködésének általánosan elterjedt részei lettek (Dunleavy-Hood [1994]). Ez a hagyományosnak tekintett államszervezet stabil környezetet feltételez, a népességet homogénen kezeli, stratégiája államközpontú (Hartley [2005]).

Az állam (a közigazgatás) és a társadalmi problémák megoldási lehetőségeinek elméleti modelljei

A 20. század utolsó harmadában a közszféra szervezetei lassan, túlzottan bürokratikusan müködtek a magánszférához képest, ezért született meg az a megállapítás, hogy a közszféra kevésbé hatékony, mint a magánszféra. A weberi állammodell kifejezetten a szabályosságra koncentrált, azt feltételezve, hogy a szabályszerü müködés meghozza a kívánt eredményt (Peters-Pierre [1998]). 
Az 1980-as évekig a weberi bürokratikus modell jelentette a demokratikus államszervezetek alapját, viszont egyre nagyobb szerepre tett szert a menedzsmentszemlélet. Ennek megvoltak az előzményei. Az egyre nagyobb méretü, de alacsony hatékonysággal müködő közszféra egyre kevésbé felelt meg a társadalmi elvárásoknak (Pongrácz [2016]). Az állami kiadások növekedését nem sikerült megakadályozni (Kovács [2014] 72. o.).

Az 1970-es évektöl kezdve felerösödtek a közszférareformok iránti igények (Christensen és szerzőtársai [2018]), az új évezredben egyre inkább elterjedtek azon nézetek, amelyek az üzleti és piaci elvek, menedzsmentmódszerek közpénzügyi szektorba való átültetését szorgalmazták. Ezek célja jellemzően az állam müködési hatékonyságának, eredményességének növelése, a transzparencia biztosítása. A téma előbb a nyugat-európai, majd az amerikai közgazdasági gondolkodásban került elötérbe. A köz- és magánszektor viszonya megváltozott, az állam erősen kontrolláló és szabályozó szerepe elavulttá vált (Peters-Pierre [1998]).

A társadalmi igények alakulása mellett nem hagyhatjuk figyelmen kívül azt sem, hogy a nemzetközi tanácsadó cégek aktívan kiálltak a magánszférában meghonosodott gyakorlatok átvétele mellett (Lapsley [2009], Oulasvirta [2014], Christensen és szerzőtársai [2018]), vagyis a weberi államigazgatástól való távolodás a vállalati szféra egyfajta érdekérvényesítésének tekinthető. Ennek illusztrálására alkalmas példa a menedzsmenttanácsadókra fordított összegek emelkedése (Lapsley [2009]). Kochanek [1996] szintén felhívta a figyelmet a vállalati lobbi szabályozásformáló hatására is.

A magánszférához való közeledés kapcsán Kernaghan [2000] másik okként állapította meg azt, hogy a szóban forgó időszakban a vállalati szférában is egyre nagyobb jelentőségre tett szert a vállalati kultúra témaköre, aminek hatására a közszférában is elindultak a menedzsmentreformok. A közigazgatásra nehezedő fokozódó nyomás végső soron államszervezeti reformokhoz vezetett. E reformokat 1. technikai, 2. érték- és részvételalapú, 3. szabályozási oldalról lehet megközelíteni (Torma [2010]). Ezek föbb jellemzőit az 1. táblázat foglalja össze.

1. táblázat

A közigazgatási menedzsmentreformok elméleti modelljei

\begin{tabular}{|c|c|c|c|}
\hline & Technikai & Érték- és részvételalapú & Szabályozási \\
\hline $\begin{array}{l}\text { Kapcsolódó } \\
\text { modell }\end{array}$ & $\begin{array}{l}\text { új közszolgálati } \\
\text { menedzsment }\end{array}$ & jó kormányzás & $\begin{array}{l}\text { neoweberiánus megközelítés/ } \\
\text { jó kormányzás irányzata }\end{array}$ \\
\hline Állam & gyenge állam & gyenge állam & erős állam \\
\hline Ideológia & piac prioritása & $\begin{array}{l}\text { civil társadalom } \\
\text { domináns részvétele }\end{array}$ & állam prioritása \\
\hline $\begin{array}{l}\text { Állami } \\
\text { szerep }\end{array}$ & lazán szabályoz, felügyel & $\begin{array}{l}\text { koordinál, felügyel, } \\
\text { szervez }\end{array}$ & irányít, erősen szabályoz \\
\hline Demokrácia & $\begin{array}{l}\text { képviseleti, reprezentatív, } \\
\text { civil szervezeti } \\
\text { konzultációval }\end{array}$ & $\begin{array}{l}\text { részvételi, széles } \\
\text { körü civilszervezeti } \\
\text { konzultációval }\end{array}$ & $\begin{array}{l}\text { többségi képviseleti, } \\
\text { közvetlen konzultációval }\end{array}$ \\
\hline
\end{tabular}

Forrás: saját szerkesztés Torma [2010] és Kovács [2014] 77. o. alapján. 


\section{A technikai megközelités és az új közszolgálati menedzsment}

A technikai megközelítés alapvetése az, hogy a legbonyolultabb társadalmi rendszerek is lebonthatók egyszerü technikai folyamatokra. A lebontás alapján létrejövő munkafolyamatok és tevékenységek pedig jellegük tekintetében nem különböznek aszerint, hogy a magánigazgatásról vagy a közigazgatásról van-e szó (Torma [2010]). Az alapfeltevés szerint az állami kiadások csökkentése, valamint a közszolgáltatások minőségének javítása a piaci koordináció és a verseny fokozásával érhető el (Rosta [2012a]). A szemlélet elsősorban az angolszász országokban tett szert gyorsan népszerüségre. Ennek oka az is, hogy míg a kontinentális Európában erős kontroll volt jellemző a közszolgáltatásokkal kapcsolatban, addig az Egyesült Államokban nem létezett az erős állam felfogása (Peters-Pierre [1998]).

Az új közszolgálati menedzsment (New Public Management, NPM) a közszféra feladatok szerint szervezett, kisebb egységekre bontását javasolta, ami által a felelősségi körök sokkal pontosabban kijelölhetők. Emellett fokozni kívánta a versenyt a közszféra szervezetei között, valamint a közszféra és a magánszektor társaságai között. Az irányzat szorgalmazza a magánszektorban alkalmazott gyakorlatok adaptálását, a hatékony erőforrás-felhasználást, a központi korlátozások mérséklését, továbbá az egyes szereplők elszámoltathatóságának növelését is. Jelentős hangsúlyt kap a standardizált teljesítménymérés és -értékelés, amellyel a hatékonyság és az elszámoltathatóság is fokozható (Hood [1995]). A versenyszellem a minőségjavulás és a költségek csökkenésének irányába hathat. A változtatások az erőforrás-felhasználás terén is növelhetik a fegyelmet. Az új közszolgálati menedzsment keretein belül az eredmények ellenőrzése és az ügyfelek igényeinek megfelelő kielégítése is sokkal nagyobb szerepet kap (Oparin Salamon [2013]). Az új közszolgálati menedzsment céljait és eszközeit a 2. táblázat foglalja össze.

Az 1980-as években az OECD-országok körében nagy népszerüségre tett szert az új közszolgálati menedzsment irányzat alapelveinek adaptálása. A korábbi államszervezetekben jellemző volt, hogy politikusok és hivatali tisztségviselők bizonyos esetekben saját érdekeiket érvényesíthették, ami növelte a költségeket, és rontotta a közösségi szolgáltatások színvonalát. Mindez felhívta a figyelmet az elszámoltathatóság fontosságára (Hood [1995]). Erre a problémára nyújt kézenfekvő megoldást, hogy azokat az állami feladatokat, amelyeket a magánszféra is meg tud oldani, ki kell szervezni, ezzel is növelve a müködési hatékonyságot (Lentner [2019] 48-49. o.). Az új közszolgálati menedzsment bevezetésének középpontjában a hatékonyság fokozása áll, ez azonban azt a veszélyt hordozza magában, hogy a közszféra müködtetése nem zajlik demokratikus alapokon (Wise [2002]).

Az új közszolgálati menedzsment irányzata a közszférára vonatkozó jelentős alapelvekkel, a közszféra és a magánszféra szétválasztásával, a menedzseri és politikai szereplők éles elhatárolásával ütközött. Ez utóbbi a korrupciót hivatott megelőzni, ezáltal tartva fenn a köz bizalmát. Az új közszolgálati menedzsment mérsékelni kívánja a köz- és magánszféra közötti különbségeket, miközben fokozná az eredmények értékelését és az elszámoltathatóságot. Ennek egyik fö eleme a könyvelési gyakorlat megújítása, az eredményszemléletű számviteli információs rendszerek közszférába való 
2. táblázat

Az új közszolgálati menedzsment céljai és eszközei

\begin{tabular}{|c|c|c|}
\hline Kategória & Célok & Példák \\
\hline $\begin{array}{l}\text { Szervezeti } \\
\text { átalakulás }\end{array}$ & $\begin{array}{l}\text { felelősség delegálása, } \\
\text { a hierarchia szintjének csökkentése, } \\
\text { a politikai és a menedzserszerepek } \\
\text { szétválasztása }\end{array}$ & $\begin{array}{l}\text { városmenedzser, } \\
\text { holdingstruktrúra }\end{array}$ \\
\hline $\begin{array}{l}\text { Menedzsment- } \\
\text { eszközök }\end{array}$ & $\begin{array}{l}\text { outputorientáció erősítése, } \\
\text { vállalkozói szellem kialakítása } \\
\text { a közigazgatásban }\end{array}$ & $\begin{array}{l}\text { teljesítménymegállapodások, } \\
\text { teljesítményalapú bérezés }\end{array}$ \\
\hline $\begin{array}{l}\text { Költségvetési } \\
\text { reformok }\end{array}$ & $\begin{array}{l}\text { üzleti szférában alkalmazott } \\
\text { pénzügyi eszközökhöz hasonló } \\
\text { technika használatának } \\
\text { elterjesztése }\end{array}$ & $\begin{array}{l}\text { költségszámítási módszerek, } \\
\text { üzemgazdasági számvitel bevezetése }\end{array}$ \\
\hline $\begin{array}{l}\text { Részvétel/ } \\
\text { partnerség }\end{array}$ & $\begin{array}{l}\text { a lakosság bevonása a döntés- } \\
\text { hozatalba és a döntések } \\
\text { előkészítésébe }\end{array}$ & $\begin{array}{l}\text { kisközösségi együttmüködések } \\
\text { támogatása, } \\
\text { e-demokrácia, } \\
\text { civil szervezetekkel való együttműködés }\end{array}$ \\
\hline $\begin{array}{l}\text { Ügyfélorientáció/ } \\
\text { minőség- } \\
\text { menedzsment }\end{array}$ & $\begin{array}{l}\text { a közszféra legitimitásának } \\
\text { fokozása a szolgáltatás } \\
\text { minőségének javításával }\end{array}$ & $\begin{array}{l}\text { egyablakos rendszer bevezetése, } \\
\text { szolgáltatásiszint-szerződések, } \\
\text { e-kormányzat }\end{array}$ \\
\hline $\begin{array}{l}\text { Piacosítás/ } \\
\text { privatizáció }\end{array}$ & $\begin{array}{l}\text { a közszektor méretének } \\
\text { csökkentése, hatékonyságának } \\
\text { növelése a verseny és a piaci } \\
\text { koordináció alkalmazásával }\end{array}$ & $\begin{array}{l}\text { privatizáció, } \\
\text { kiszervezések, } \\
\text { a közfeladatok ellátása magántőke- } \\
\text { bevonással, } \\
\text { közbeszerzési eljárások }\end{array}$ \\
\hline
\end{tabular}

Forrás: Rosta [2012b].

átültetése (Hood [1995]). Az új közszolgálati menedzsment versenykörnyezetet feltételez, a népességet kisebb csoportokra osztja. Az igényeket nem szakértők állapítják meg, mint a weberi állam esetében, hanem a piaci igények alakulásán keresztül vizsgálják, a stratégia piac- és fogyasztóközpontú (Hartley [2005]).

$\mathrm{Az}$ új közszolgálati menedzsment hatásait nehéz általánosságban értékelni. Az egyes országok reformjai jelentős különbségeket mutatnak. Az irányzat nem fogalmaz meg ideológiai alapokat, a döntéshozók a módszerek között válogathatnak, feladatukhoz tartozik az állam céljaihoz illeszkedő innovációk bevezetése. Az új közszolgálati menedzsment szervezeti szintű és rendszerszintű javaslatokat is megfogalmaz (Rosta [2012b]). Feltételezték, hogy képes a közszférát hatékonyabbá, gazdaságosabbá és eredményesebbé tenni, de ezeket a célokat legtöbbször nem sikerült elérni (Lapsley [2009]). Báger [2006] felhívta arra a figyelmet, hogy az üzleti szféra bevonása növelte a kockázatokat, valamint a kiszervezések sokszor drága és gyenge minőségü közjavakat, közszolgáltatásokat eredményeztek. Dunn-Miller [2007] szerint az új közszolgálati menedzsment bevezetésével elmaradtak a várt eredmények, $s$ háttérbe szorult az etikus viselkedés. Maesschalk [2004] is kiemelte, hogy egyre terjedt a korrupció és az 
etikátlan viselkedés az OECD-országok körében. Christensen-Laegreid [2007] pedig a horizontális koordináció problémájára hívta fel a figyelmet, míg Lynn [2008] azt emelte ki, hogy sok esetben a reformok társadalmi egyeztetés által biztosított legitimációja is hiányzik. Dunleavy-Hood [1994] rávilágított arra, hogy a korrupció és az etikátlan viselkedés nem küszöbölhető ki teljesen semmilyen menedzsmentrendszerrel, valamint arra is, hogy az új közszolgálati menedzsment ilyen jellegü kockázatai mérsékelhetők a civil szféra megerösítésével (Randma-Liiv [2008]).

Az új közszolgálati menedzsment irányzata a posztszocialista országokban is népszerü volt. Az állampolgárok az 1990-es évek elején elfogadhatónak találták a deregulációt és a privatizációt, amelyekre épült az új közszolgálati menedzsment is (RandmaLiiv [2008]). A posztszocialista országok - tradicionális államszervezet hiányában motiváltak voltak a sikeres országok módszereinek átvételében. A reformokkal kapcsolatban azonban ki lehet emelni azt a tényt, hogy figyelmen kívül hagyták az eltérő kiinduló helyzetet. A posztszocialista országokban a magánszféra még nem volt hatékony, nem léteztek jól müködő piacok, így nem is lehetett feltételezni, hogy érvényesülnek a kívánt hatások (Randma-Liiv [2008]).

Bár a közszolgálati menedzsmentreformok eredményessége vitatható, az kétségtelen, hogy a közszférák számviteli rendszereinek fejlődésében kulcsszerepet játszott az irányzat (Christiaens-Rommel [2008]). E reformok egyik legnagyobb eredményének az - elsősorban a magánszférára jellemző - eredményszemléletű számviteli rendszerek közszférában való megjelenését szokás tekinteni. Bár az eredményszemléletű számvitelre való áttérés a rendszer alapjainak megváltoztatását jelenti (lásd bővebben Kovács-Deák [2012]), ez nem mindig járt együtt más reformokkal. A könyvelési gyakorlat által biztosított elszámoltathatóság és transzparencia más elméletek (mint például a jó kormányzás) esetében is központi kérdés. Ezzel összhangban áll az a megfigyelés is, amely szerint az eredményszemléletü könyvelés elterjedése kisebb ellenállásba ütközött, mint az új közszolgálati menedzsment javaslatainak többsége. Ennek okai közé sorolható, hogy a könyvelési rendszer megváltoztatása kisebb mértékủ szervezeti változásokkal jár, mégis képes kielégíteni a polgárok igényét a magasabb szintű elszámoltathatóság és transzparencia iránt (Pina és szerzőtársai [2009]).

\section{Érték- és részvételalapú megközelités és a jó kormányzás irányzata}

Az érték- és részvételalapú megközelítés központi gondolata az, hogy a közügyekben való döntés nem a bürokrácia kiváltsága, hanem a döntéseket az érdekeltek (érintettek) bevonásával kell meghozni. A modell a közszolgálati menedzsmenttel ellentétben nem az üzleti, hanem a civil szférát helyezi a középpontba. A döntéshozatalt kompromisszumkeresés és széles társadalmi konzultáció jellemzi (Kovács [2014] 77. o.). Az irányzat a Világbank által az 1980-as években megfogalmazott javaslatokhoz köthetö (Pályi [2015]), G. Fodor-Stumpf [2007] a neoliberalizmussal kapcsolja össze a jó kormányzás fogalmát.

Az e koncepcióhoz füződő döntések törekednek a joguralom biztosítására (rule of law), valamint a jogbiztonság erösítésére. Fontos elem az átláthatóság és az 
elszámoltathatóság garantálása, a döntéshozók bírálatának lehetősége, a civil tiltakozások kifejezésének intézményesített fejlesztése. Mindezekkel összhangban a korrupció háttérbe szorítása is fontos cél. Az érintettek bevonásával, az átláthatóság biztosításával és a számonkérhetőséggel javítható a kormányzás minősége. A jó kormányzás keretein belül az állam elsősorban a szabályozás eszközeivel él, inkább közvetítő szerepet tölt be a különböző társadalmi rétegek között, allokációs és redisztribúciós szerepe a hagyományosnál korlátoltabb (Kovács [2014] 74-77. o.). A demokrácia megerösítése iránti növekvő igény az intézmények kialakítására is hatással van. Az átláthatóság fokozása kulcsfontosságú eleme a demokrácia támogatásának. A koordináció inkább társadalom-központúnak (és ezáltal kevésbé államközpontúnak és piaci központúnak) tekinthetö (Lynn [2008]). Báger és szerzőtársai [2010] szerint a civil társadalom bevonása a gazdaságpolitika kialakításába, valamint hatékony együttmüködése az állammal javíthatja a versenyképességet. Az érték- és részvételalapú megközelítésben a formális és informális elemek egyformán jelentősek, a társadalmi önszabályozás lép azállam helyébe. A végső kontrollt a társadalmi nyilvánosság gyakorolja, amely képes megítélni az egyes érvek észszerüségét és normatív igazságtartalmát (Stumpf [2009]).

A modell alkalmazása viszont csak akkor lehet eredményes, ha az adott országban erős a középosztály, s képes és hajlandó részt venni a közpolitikai döntéshozatalban. A megközelítés kockázata az, hogy a közigazgatástól teljes (nagyobb) nyitottságot vár el, a polgároktól pedig azt igényli, hogy akarjanak és tudjanak is közremüködni a közpolitikai döntések meghozatalában. Az irányzat olyan társadalmat feltételez, ahol a lakosság képes élni és élni is akar az állam által felkínált beavatkozási lehetőségekkel (Torma [2010]). A jó kormányzás esetében problémát jelent az is, hogy nincs olyan gazdasági szereplö, aki képes lenne biztosítani a közösségek és egyének jólétét, valamint akin ezt a feladatot számon is lehetne kérni (Kovács [2014] 76. o.). Ráadásul az egyes társadalmi csoportok nem rendelkeznek egyenlő érdekérvényesítő képességgel, így kétely merülhet fel azzal kapcsolatban, hogy mely érdekcsoportok és milyen céllal támogatják ezt az irányzatot, valamint azzal is, hogy a civil szféra érdekérvényesítése mennyire valósulhat meg a vállalati szféra ereje mellett. Mindezek következtében a döntéshozatal hatékonysága és minősége kérdésessé válhat. G. Fodor-Stumpf [2007] is kiemeli, hogy az irányzattal kapcsolatos egyik főbb kritika az, hogy a magánszervezetek koordinációs szerepének a lehetővé tétele a nagy erejü gazdasági társaságok érdekérvényesítésének nyit teret. Ez pedig rontja a demokrácia képviseleti funkcióját.

A jó kormányzás általános ismérve a törvényeket, szabályokat követő magatartás, valamint az esélyegyenlőséget biztosító, mások elképzeléseit befogadó szabályozás. Az állam tevékenysége konszenzusképes, valamint a civil társadalmat részvételre, kooperációra ösztönözi. Az állam működését célszerü és eredményes gazdálkodás jellemzi, valamint a rugalmas reagálóképesség. A kormányzat tevékenysége elszámoltatható, transzparens (Pályi [2015]). A jó kormányzással foglalkozó tanulmányok megállapítják, hogy a javaslatok érvényesítése elősegíti a növekedést és a társadalmi fejlődést (G. Fodor-Stumpf [2007]). A jó kormányzás alapelvei szerint több nemzetközi gazdasági, pénzügyi, fejlesztéspolitikai szervezet is fogalmazott meg kritériumokat, illetve fejlesztett ki az értékelésre alkalmas indexeket (Pályi [2015]). A jó kormányzás elméleti modelljét a 2. ábra foglalja össze. 
2. ábra

A jó kormányzás elméleti modellje

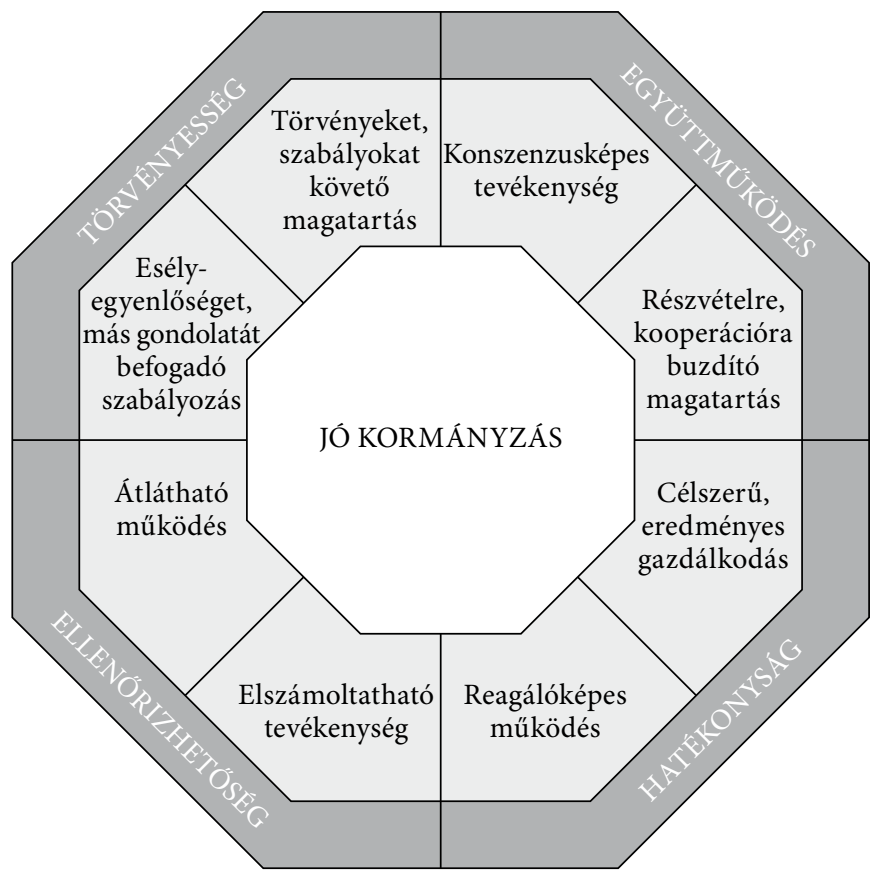

Forrás: saját szerkesztés Netherlands Court of Audit [2014] 18. o. alapján.

\section{A szabályozási megközelítés és a neoweberiánus elmélet}

A szabályozási szemlélet azt hangsúlyozza, hogy az államnak a felmerülö problémákat szabályozás útján kell megoldania: módosítania kell a régi szabályokat, vagy újakat kell létrehoznia. A középpontba helyezett szabályalkotás nem egyszerüen csak a jogalkotást, hanem a jogalkalmazást és annak ellenőrzését is magában foglalja. A szabályozási megközelítés az állam jelentőségét emeli ki, és alkalmas arra, hogy a polgárok és a szervezetek magatartását az állam által kívánt irányba terelje. Ez véghez vihető a jogszabályok kötelező erejével, valamint azok megsértése esetében szankciók érvényesítésével, valamint különböző ösztönzők segítségével. A szabályozási megközelítés a neoweberiánus állam elméleti alapjának tekinthető (Torma [2010]).

A neoweberiánus állam koncepciójának említése Pollitt-Bouckaert [2004] munkájához köthető, és négy alapelvre támaszkodik: 1 . az állam középpontba helyezése, 2. a közigazgatás szabályainak megújítása és alkalmazása, 3. a közszolgáltatások megőrzése, valamint 3. a reprezentatív demokrácia (Dunn-Miller [2007]). A problémamegoldás aktora a demokratikus kormány, amelynek célja a közjó biztosítása (Stumpf [2009]).

Bár az állam gazdaságban betöltött szerepében nagyok a különbségek, Pályi [2015] szerint a jó kormányzáson - mindenféle ideológiai megkülönböztetéstől 
eltekintve - a közjó érvényesülése érdekében kifejtett hatékony, eredményes, megbízható, átlátható és felelős tevékenységet kell érteni. Mindezek együttes hatásaként az állami szervezetek az érdekeltekkel együttmüködve, a köz érdekét szem elött tartva keresnek megoldást az adott időszak aktuális gazdasági, társadalmi, környezeti kihívásaira. Ehhez pedig aktív, intelligens és erős állam szükséges. Az államnak fel kell lépnie, hogy a közérdeket érvényre juttassa, de a társadalom széles körü részvétele sem nélkülözhető.

Amíg az új közszolgálati menedzsment az angolszász országokhoz köthető, a neoweberiánus államok elsősorban a kontinentális Európában jelentek meg (DunnMiller [2007]). Ez utóbbi megközelítés nem feltételezi, hogy a magánszektor közszolgáltatásai jobbak, de ezek igénybevételét sem veti el. Az állam erősítése és hatékony müködése bizonyos esetekben jobban biztosítható a magánszektor bevonásával és üzleti módszerek alkalmazásával (Pollitt [2008]). Dreschler [2005] négy olyan jellemzőt emelt ki, amely megfelel a neoweberiánus megközelítésnek, viszont az új közszolgálati menedzsment gondolataival is egybevág: 1 . nyitottság a lakossággal szemben, 2. társadalmi konzultációk és a lakosság közvetlen részvétele, 3. eredményközpontúság, valamint 4. a professzionális vezetés. Dunn-Miller [2007] megállapítja, hogy a két irányzat nem szöges ellentéte egymásnak, viszont az állam szerepéröl alkotott véleményük között jelentős eltérés figyelhető meg.

\section{3. táblázat}

A weberiánus és a neoweberiánus állam főbb jellemzői

Weberiánus jellemzők

Az állam vezető szerepének megerősítése a globalizáció, a technológiai változások és a demográfiai, valamint környezeti kihívásokra adandó válaszok keresésében

A reprezentatív demokrácia szerepének erősítése mint az államapparátus legitimációjának bázisa (központi, regionális és helyi szinten egyaránt)
A közigazgatási jog szerepének megerősítése annak érdekében, hogy bázisaként funkcionáljon az állampolgárok és az állam közötti kapcsolatok kialakításában, beleértve ebbe a törvény elötti egyenlőséget, a jogbiztonságot és a társadalmi folyamatokba történő állami beavatkozások részletekbe menő jogi szabályozását

A közszolgálat jól elhatárolt státusának, kultúrájának és szabályrendszerének fenntartása

\section{Neoweberiánus jellemzők}

Külső orientáció, az állampolgárok igényeinek és kívánságainak teljesítése (a belső orientáció és a bürokratikus szabályok helyett)

A reprezentatív demokrácia kiegészítése konzultációs és az állampolgárok véleményét közvetlenül megjelenítő eszközökkel

A jogrendszer modernizálása annak érdekében, hogy az államigazgatáson belüli erőforrásokat inkább eredményorientáltan, mintsem az elöírásokhoz túlzottan ragaszkodva használják fel. Az ellenőrzés hangsúlya így az előzetes ellenőrzésről az utólagos ellenőrzésre kerül át
A közszolgálat professzionalizálódása: a közszolgák túl azon, hogy jogi szakértelmüket alkalmazzák, szakmai kompetenciákkal rendelkező menedzserekké is válnak 
A neoweberiánus megközelítés jelentősen változott a régebbi weberihez képest, ugyanis a bürokrácia kialakítása során nagyobb figyelmet fordít a társadalmi igényekre, valamint a bürokraták szabálykövető magatartásának megkövetelése mellett (amely a weberi filozófia alapvető vonása) a menedzseri szemlélet alkalmazását is ösztönözi (3. táblázat). Stumpf [2009] szerint ez nem az új közszolgálati menedzsment és a weberiánus szervezés keverését jelenti, csupán azt, hogy a neoweberiánus államigazgatás az új közszolgálati menedzsment olyan elemeit is alkalmazza, amelyek nem állnak szemben a weberi államszervezet logikájával.

A neoweberiánus államszervezés kockázatának tekinthetjük, hogy a szervezeteket eltéríthetik az eredeti céljuktól, ezáltal a legitimitásuk is megkérdőjeleződik. Mindemellett a sokszor antidemokratikus elemek is megjelenhetnek ilyen jellegü államszervezetek müködésében (Lynn [2008]). Az irányzat kritikusai szerint elöfordulhat, hogy a kormányzati hatalommal szemben nem müködnek megfelelöen a „fékek és ellensúlyok”, valamint az ezt képviselö intézmények súlya is csökken (Kovács [2014] 78. o.).

Magyarországon ez a megközelítés 2010-et követően az államigazgatás újjászervezésekor a Magyary Zoltán Közigazgatás-fejlesztési Program keretében vált dominánssá. A neoweberiánus állam nem tagadja meg az új közszolgálati menedzsment irányzatot, figyelembe veszi annak javaslatait, viszont nem fogadja el azt az elvet,

\section{3. ábra}

Az államszervezési elméletek relációja

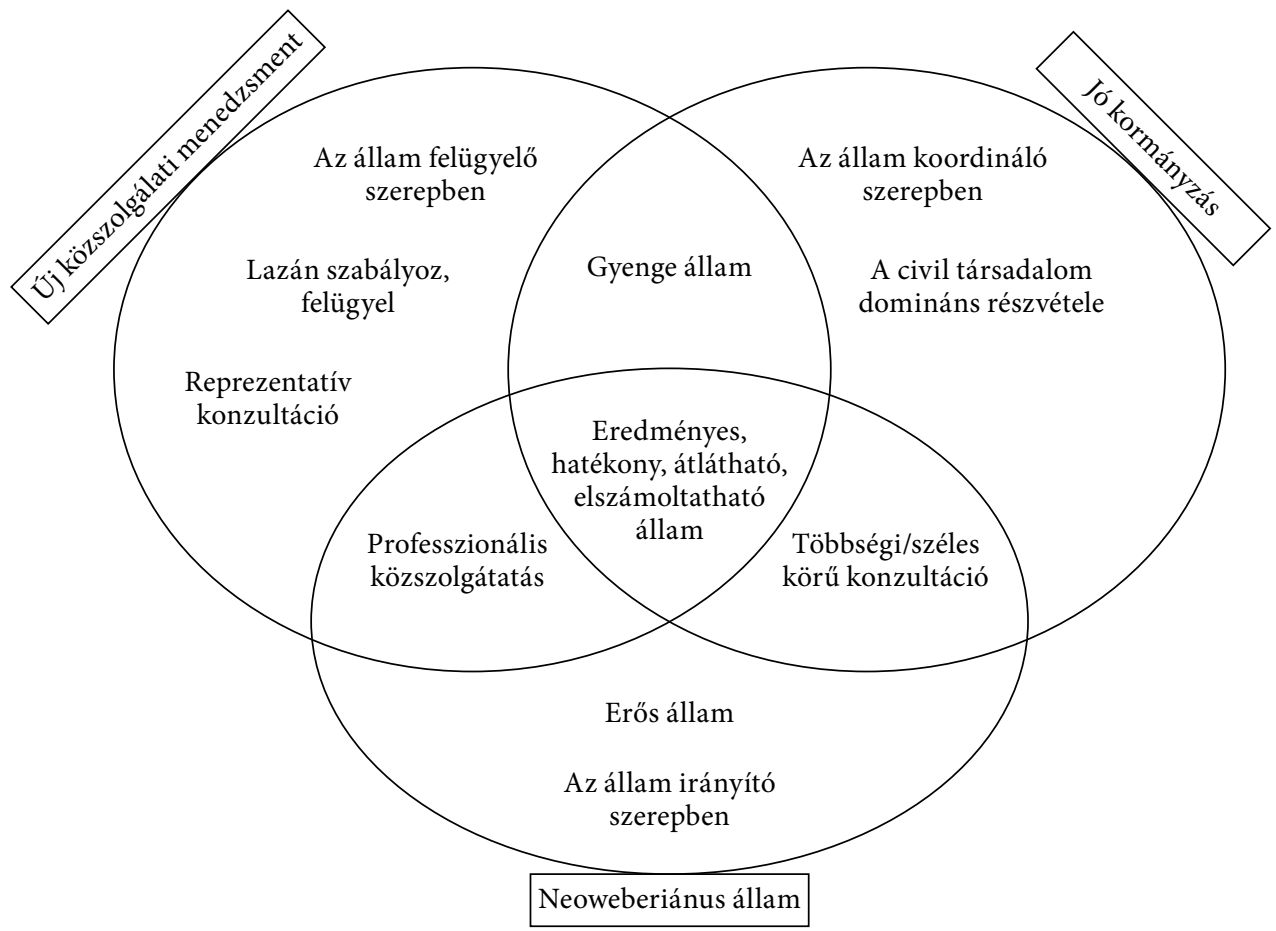

Forrás: saját szerkesztés. 
amely szerint a közszférát a magánszférához hasonlóan lehet üzemeltetni (Rosta [2015]). Mint ahogy a 3. ábra is mutatja, az elméletek államkoncepciói között van átfedés, ezek nem állnak teljesen szemben egymással. Sőt a végső cél azonos: az eredményes, hatékony, transzparens, elszámoltatható állam létrehozása.

\section{Összegzés}

Az állam funkcióira vonatkozó irányzatok és a müködtetésükben alkalmazott módszerek körében bekövetkező változások nem tekinthetők egymástól teljesen függetlennek. Fontos szerep jut az állam és a piac közötti viszony meghatározásának és a verseny megítélésének. A keynesiánus paradigma háttérbe szorulásával párhuzamosan a weberi államfelfogásba vetett hit is megingott. Mindkét fronton elsősorban az angolszász országok esetében figyelhettük meg ezeket a változásokat, míg a kontinentális Európában (ahol a weberi államszervezetnek nagyobb hagyományai voltak) nem indultak el gyorsan ilyen jellegü változások. Igaz, az Európai Unió perifériaországaiban az új közszolgálati menedzsment irányzata jelentős befolyást gyakorolt, amiben nagy szerepe volt a jelentős nemzetközi szervezetek ajánlásainak. A mainstream gazdaságpolitika és az új közszolgálati menedzsment összhangját több szerző is kiemelte, illetve e paradigmához kapcsolható a jó kormányzás irányzata is. Az új közszolgálati menedzsment hiányosságaira reagálva erősödtek meg a neokeynesiánus irányzatok.

Az új közszolgálati menedzsment, a jó kormányzás és a neoweberiánus elméletek által hirdetett intézkedések között átfedések is megfigyelhetök. Az állam transzparenciáját, ellenőrizhetőségét és elszámoltathatóságát mindegyik megközelítés fontosnak tartja, az alkalmazott módszerek szervezeti szinten nagyon hasonlók. Ennek talán legszemléletesebb példája az eredményszemléletű számvitel megjelenése a közszférákban, a melyet mindhárom irányzat támogat. A különbséget az államnak szánt szerepben találhatjuk: az új közszolgálati menedzsment az állam szerepét csökkenteni, a neoweberiánus megközelítés erősíteni kívánja, míg a jó kormányzás irányzata az állam különböző társadalmi csoportok közötti koordinációs szerepét hangsúlyozza.

\section{Hivatkozások}

BÁGER GuszTáv [2006]: A köz- és magánszféra együttmüködése és a számvevőszéki ellenőrzés. Pénzügyi Szemle, 51. évf. 1. sz. 57-78. o.

BÁger Gusztáv-Pulay Gyula-Vígvári András [2010]: A magyar államműködés jellemzői és a szükséges változtatások irányai. Pénzügyi Szemle, 55. évf. 2. sz. 217-243. o.

Bouckaert, G.-Vitalis, N.-Nemec, J. [2011]: Public Administration and Management Reforms in CEE: Main Trajectories and Results. The NISPAcee Journal of Public Administration and Policy, Vol. 4. No. 1. 9-29. o. https://doi.org/10.2478/v10110-011-0001-9.

Christensen, M.-Newberry, S.-Potter, B. N. [2018]: Enabling global accounting change: Epistemistic communities and the creation of a 'more business-like' public sector. Critical Perspectives on Accounting, Vol. 58. 53-76. o. https://doi.org/10.1016/j.cpa.2018.04.006. 
Christensen, T.-Laegreid, P. [2007]: The Whole-Government Approach to Public Sector Reform. Public Administration Review, Vol.67. No. 6. 1059-1066. o. https://doi.org/10.1111/ j.1540-6210.2007.00797.x.

Christiaens, J.-Rommel, J. [2008]: Accrual Accounting Reforms: Only for Businesslike (Parts of) Governments. Financial Accountability and Management, Vol. 24. No. 1. 59-75. o. https://doi.org/10.1111/j.1468-0408.2008.00443.x.

Csaba LÁszló [2010]: Keynesi reneszánsz? Pénzügyi Szemle, 54. évf. 1. sz. 5-22. o.

Csaba László [2018]: A 21. század a világ közgazdaságtanában. Köz-Gazdaság, 13. évf. 2. sz. 113-126. o. https://doi.org/10.14267/RETP2018.02.26.

DiMaggio, P. J.-Powell, W. W. [1983]: The Iron Cage Revisited: Institutional Isomorphism and Collective Rationality in Organizational Fields. American Sociological Review, Vol. 48. No. 2. 147-160. o. https://doi.org/10.2307/2095101.

Dreschler, W. [2005]: The rise and demise of the new public management. Post-autistic Economics Review, Vol. 33. No. 14. 17-28. o.

Dunleavy, P.-Hood, C. [1994]: From Old Public Administration to New Public Management. Public Money \& Management, Vol. 14. No. 3. 9-16. o. https://doi.org/10.1080/ 09540969409387823.

Dunn, W. N.-Miller, D. Y. [2007]: A Critique of the New Public Management and the NeoWeberian State: Advancing a Critical Theory of Administrative Reform. Public Organization Review, Vol. 7. No. 4. 345-358. o. https://doi.org/10.1007/s11115-007-0042-3.

FARKAS PÉTER [2011]: Mégis szükség van gazdaságszervező államra? Gazdaság és Társadalom, 3. évf. 2. sz. 39-60. o. https://doi.org/10.21637/gt.2011.2.04.

FARKAS PÉTER [2017]: Az állam szerepével kapcsolatos gazdaságelméletek módosulása a világgazdasági válságok nyomán. 1-2. Köz-Gazdaság, 12. évf. 2. sz. 41-64. o. és 5. sz. 127-149. o.

G. Fodor GÁbor-STumpf István [2007]: A jó kormányzás két értelme. Avagy a demokratikus kormányzás programja és feltételei. Nemzeti Érdek, 1. évf. 3. sz. 76-94. o.

Hartley, J. [2005]: Innovation in Governance and Public Services: Past and Present. Public Money and Management, Vol. 25. No. 1. 27-34. o.

Hood, C. [1995]: The "new public management" in the 1980s: Variations on a theme. Accounting, Organisation and Society, Vol. 20. No. 2-3. 93-109. o. https://doi.org/10.1016/03613682(93)e0001-w.

Jenei György [2016]: Max Weber bürokráciaelmélete és a neoweberiánus szintézis. Pro Publico Bono - Magyar Közigazgatás, 4. évf. 3. sz. 42-55. o.

Kaplan, B. H. [1968]: Notes on a Non-Weberian Model of Bureaucracy: The Case of Development Bureaucracy. Administrative Science Quarterly, Vol. 13. No. 3. 471-483. o. https:// doi.org/10.2307/2391054.

Kernaghan, K. [2000]: The post-bureaucratic organization and public service values. International Review of Administrative Sciences, Vol. 66. No. 1. 91-104. o. https://doi. org/10.1177/0020852300661008.

KochANEK, S. A. [1996]: Liberalisation and business lobbying in India. Journal of Commonwealth \& Comparative Politics, Vol. 34. No. 3. 155-173. o. https://doi.org/10.1080/ 14662049608447729.

KоLорко, G. W. [2000]: A posztszocialista átalakulás tíz éve - a gazdaságpolitikai reformokkal kapcsolatos tanulságok. Közgazdasági Szemle, 47. évf. 3. sz. 197-214. o.

KovÁcs ÁRPÁD [2014]: Vázlatos betekintés a közpénzügyi döntéshozatalba. Oktatáskutató és Fejlesztő Intézet, Budapest. 
Kovács Zsuzsanna Ilona-DeÁk István [2012]: Számvitel - szakma versus tudomány. Pénzügyi Szemle, 57. évf. 4. sz. 458-468. o.

Kuhlmann, S.-Bogumil, J.-Grohs, S. [2008]: Evaluating Administrative Modernization in German Local Governments: Success or Failure of the "New Steering Model"? Public Administration Review, Vol. 68. No. 5. 851-863. o. https://doi.org/10.1111/j.15406210.2008.00927.x.

LApsLey, I. [2009]: New Public Management: The Cruellest Invention of the Human Spirit? Abacus, Vol. 45. No. 1. 1-21. o. https://doi.org/10.1111/j.1467-6281.2009.00275.x.

Lentner Csaba [2019]: Önkormányzati pénz- és vagyongazdálkodás. Dialóg Campus, Budapest.

LynN, L. E. [2008]: What is a Neo-Weberian State? Reflection on a Concept and its Implications. The NISPAcee Journal of Public Administration and Policy, Vol. 1. No. 2. 17-30. o.

Maesschalk, J. [2004]: The Impact of New Public Management Reforms on Public Servants' Ethics: Towards a Theory. Public Administration, Vol. 82. No. 2. 465-489. o. https://doi. org/10.1111/j.0033-3298.2004.00403.x.

Meyer-SAhling, J. [2009]: Varieties of legacies: a critical review of legacy explanations of public administration reforms in East Central Europe. International Review of Administrative Sciences, Vol. 75. No. 3. 509-528. o. https://doi.org/10.1177/0020852309337670.

Meyer-Sahling, J.-Yesilkagit, K. [2011]: Differential Legitacy Eddects: Three propositions on the impact of administration reform in Europe East and West. Journal of European Public Policy, Vol. 18. No. 2. 311-322. o. https://doi.org/10.1080/13501763.2011.544515.

Muraközy LÁszLó [2009]: Állam és piac Magyarországon. Spontán rend vagy bürokratikus rendetlenség. Közgazdasági Szemle, 61. évf. 3. sz. 270-288. o.

Netherlands Court of Audit [2014]: Annual Report 2013. https://english.rekenkamer.nl/ publications/annual-reports/2014/03/25/annual-report-2013.

Oparin Salamon Melinda [2013]: A közmenedzsment evolúciója: az új közmenedzsmenttől a hálózati kormányzásig. Marketing \& Menedzsment, 47. évf. 1. sz. 77-88. o.

OulasvirTa, L. [2014]: The reluctance of a developing country to choose International Public Sector Accounting Standards of the IFAC. A critical case study. Critical Perspectives of Accounting, Vol. 25. No. 3. 272-285. o. https://doi.org/10.1016/j.cpa.2012.12.001.

PÁlyi Katalin ÁGnes [2015]: A Számvevőszék hozzájárulása a jó kormányzáshoz és a számvitel megújulásához. Pénzügyi Szemle, 60. évf. 4. sz. 536-556. o.

Peters, G. B.-Pierre, J. [1998]: Governance Without Government? Rethinking Public Administration. Journal of Public Administration Research and Theory, Vol. 8. No. 2. 223-243. o. https://doi.org/10.1093/oxfordjournals.jpart.a024379.

Pina, V.-Torres, L.-Yetano, A. [2009]: Accrual Accounting in EU Local Governments: One Method, Several Approaches. European Accounting Review, Vol. 18. No. 4. 765-807. o. https://doi.org/10.1080/09638180903118694.

Pollitt, C. [2008]: An Overwiew of the Papers and Propositions of the First Trans-European Dialogue. The NISPAcee Journal of Public Administration and Policy, Vol. 1. No. 2. 9-16. o.

Pollitt, C.-Bouckaert, G. [2004]: Public Management Reform. A Comparative Analysis. Second Edition. Oxford University Press, Oxford.

Pongrácz Alex [2016]: A közmenedzsment-reformok metamorfózisai. Új Magyar Közigazatás, 9. évf. 1. sz. 1-12. o.

Randma-Liıv, T. [2008]: New public management versus neo-Weberian State in Central and Eastern Europe. The NISPAcee Journal of Public Administration and Policy, Vol. 1. No. 2. 69-82. o. 
Rosta Mikıós [2012a]: Az új közszolgálati menedzsment célja. Társadalomkutatás, 30. évf. 2. sz. 169-185. o.

Rosta MikLós [2012b]: Az új közszolgálati menedzsment és a Magyary Zoltán Közigazgatásfejlesztési Program viszonyáról. Polgári Szemle, 8. évf. 3-6. sz. https://polgariszemle. hu/archivum/114-2012-december-8-evfolyam-3-6-szam/szemelvenyek-az-allam-eskozigazgatas-tudomanybol/496-az-uj-koezszolgalati-menedzsment-es-a-magyary-zoltankoezigazgatas-fejlesztesi-program-viszonyarol.

Rosta Miklós [2015]: Kakofónia a közmenedzsmentben. A New Public Management és a Post-New Public Management kapcsolata. Köz-Gazdaság, 10. évf. 3. sz. 205-218. o.

Serpa, S.-Ferreira, C. M. [2019]: The Concept of Bureaucracy by Max Weber. International Journal of Social Science Studies, Vol. 7. No. 2. 12-18. o. https://doi.org/10.11114/ ijsss.v7i2.3979.

Stiglitz, J. E. [1999]: More Instruments and Broader Goals: Movin Toward the PostWashington Consensus. https://academiccommons.columbia.edu/doi/10.7916/D8K93JGF/ download.

STUMPF István [2009]: Az állam újrafelfedezése és a neoweberiánus állam. Megjelent: Virág György (szerk.): ORKI Szemle, 1. kötet. Megjelent az ORKI fennállásának 50. évfordulója alkalmából. 110-123. o.

Szentes Tamás [2006]: Az állam szerepe a felgyorsult globalizációban. Köz-Gazdaság, 1. évf. 1. sz. $15-46.0$.

Torma András [2010]: Adalékok a közmenedzsmentreformok elméleti hátteréhez és főbb irányzataihoz. Publicationes Universitatis Miskolcinensis, Sectio Juridica et Politica, Vol. 28. No. 1. 315-328. o.

VoszKa Éva [2015]: Államosítás, privatizáció és gazdaságpolitika - a főirány széttöredezése. Közgazdasági Szemle, 62. évf. 7-8. sz. 717-748. o.

WADE, R. [2010]: After the Crisis: Industrial Policy and the Developmental State in LowIncome Countries. Global Policy, Vol. 1. No. 2. 150-161. o. https://doi.org/10.1111/j.17585899.2010.00036.x.

WADE, R. [2014]: 'Market versus State' or 'Market with State': How top Impart Dicertional Thrust. Developement and Change, Vol. 45. No. 4. 777-798. o. https://doi.org/10.1111/ dech.12099.

Weber, M. [1968]: The Theory of Social and Economic Organization. The Free Press, New York.

Weber, M. [1970]: Állam, Politika, Tudomány. Közgazdasági és Jogi Könyvkiadó, Budapest. Wise, L. R. [2002]: Public Management Reform: Competing Drivers of Change. Public Administration Review, Vol. 62. No. 5. 556-567. o. https://oi.org/10.1111/1540-6210.00237.

Wright, V. [1994]: Reshaping the state: The implications for public administration. West European Politics, Vol. 17. No. 3. 102-137. o. https://doi.org/10.1080/01402389408425032. 